\title{
Socio-Economic Determinants of Infant and Child Mortality Rate: The Case of Humbo Woreda, Snnpr, Ethiopia
}

\author{
Hailu Sodana Teka \\ Department of Economics, Wolaita Sodo University,PO Box 138, Wolaita Sodo, Ethiopia
}

\begin{abstract}
Background: Childhood mortality rate is the result of many social and economic factors than simple health crisis. The main aim of this study was analyzing the effect of socio-economic characteristics of households on infant and child mortality rate in Humbo Woreda, Wolaita Zone. This is important for revising the existing health, education, and economic programs and policies to meet GTPE. Methods: The study employed a cross-sectional type of data set which consists of a sample of households taken at a given point in time. Data was collected from 202 households using semi-structured questionnaires and interview schedule. Stratified random sampling method was used as sampling technique. The data was analyzed using both descriptive and econometric (logit) regression analysis. The study involved two dependent variables namely; IMR \& CMR. Results: IMR of the Humbo woreda is 50 and it has shown about $15 \%$ reduction over the past 8 years. The current CMR of the Woreda is 48 and has shown about $25 \%$ reduction over this period. Working status of mother, level of mother education, access to health facilities, place of household residence, and access to safe water are determining IMR whereas access to safe water, level of father education, household size, working status of mother, occupational status of household heads, marital status of parents, and accesses to health facilities are determining CMR in the district. Conclusion: The study concluded that socio-economic factors such as working status of mother, mother education, access to health facilities, place of household residence, and access to safe water were the major determinants of IMR whereas access to safe water, father education, household size, working status of mother, occupational status of household heads, marital status of parents, and access to health facilities were the major determinants of CMR in the district. Community-based intervention is required and should focus on child spacing, improve access to parent's education, access to health facilities, access to safe water and poverty eradication programs, particularly in rural areas.
\end{abstract}

Keywords: IMR, CMR, Logit Model.

DOI: $10.7176 / \mathrm{JESD} / 10-13-01$

Publication date:July $31^{\text {st }} 2019$

\begin{abstract}
Abbreviations
ICF: International Children Fund; CLRM: Classical Linear Regression model; CMR: Child Mortality Rate; CSA: Central Statistics Agency; EDHS: Ethiopian Demographic and Health Survey; FMoH: Federal Ministry of Health; GTPE: Growth and Transformation Plan of Ethiopia; IMR: Infant Mortality Rate; MDGs: Millennium Development Goals; UNMDGs: United Nation's Millennium development Goals; VIF: Variance Inflation Factor
\end{abstract}

\section{INTRODUCTION}

Poorer families have poor socio-economic conditions and hence higher exposure to illness and death. Among the indicators of socioeconomic and health conditions, infant and child mortality rate is the one that is most frequently facing the developing countries (Mutunga, 2007). In spite of the substantial drop in global childhood mortality rate, about 5.9 million children still die every year before their fifth birthday worldwide. Reducing childhood mortality rate to minimum level is thus a focus of every community and requires improvements in socio-economic status of the population as well as improvements in the direct services. More recently, Ethiopia has outlined the strategic plan to reduce infant mortality to $16 / 1000$ live births and child mortality rate to below 30 deaths per thousand live children by the year 2035 (FMoH, 2014). Figures on vital health indicators show that infant and child mortality rates in national level for the survey year of 2011 are 48 and 58 respectively. These are still higher than GTPE levels and calls for special attention (CSA, 2016). People in the study area are still facing a high rate of childhood morbidity and mortality. Majority of the population remain chronically food insecure and are vulnerable to shocks and potential disasters. Previously, almost no studies have been done except simple Health Surveys on clinical factors only. This study was motivated to identify and analyze the main causes of infant and child mortality in the Woreda.

\section{OBJECTIVES OF THE STUDY}

The general objective

The general objective of this study was to identify and analyze the effect of socio-economic factors on infant and child mortality rate in Humbo Woreda, SNNPR.

The specific objectives

- To determine the levels of IMR and CMR; 
- To determine the trends and differentials of IMR and CMR in the district;

- To analyze level of effect of socio-economic factors on IMR and CMR in the district;

\section{MATERIALS AND METHODS}

Description of the Study Area

This research was conducted in Humbo Woreda, Wolaita Zone. It is located at $418 \mathrm{~km}$ south from Addis Ababa. Agro-ecology of the Woreda is 30\% moderate or Woynadega and 70\% lowland or "kola". The average temperature ranges between $15^{\circ} \mathrm{C}$ and $29^{\circ} \mathrm{C}$ and the altitude ranges from 1100 to $2800 \mathrm{~m}$ above sea level. The population of the Woreda is estimated to be 162,306 in 2016; of the total population, $50.3 \%$ and $49.7 \%$ are males and females respectively. The total households of the Woreda are estimated to 20,223; of which 16,519 are rural dwellers and 3,704 are urban dwellers.

\section{Research design}

The study used quantitative data types to investigate the mortality level \& trends. The study employed a crosssectional type; both primary and secondary data sources; stratified random sampling method as sampling techniques; children of age 1-12 months \& children of age 12-59 months as the unit of analysis; 202 respondent households as sample size; and both descriptive and econometric analysis as method of data analysis .

Descriptive analysis

The levels, trends and differentials of mortality rates were calculated by considering total live births, total deaths and total survives in the woreda.

\section{Econometric analysis}

The effect of socio-economic factors on infant and child survival was analyzed using binary logit model.

Model Specification

The study involved two models; both models attempted to capture the socio-economic characteristics of households that affect IMR and CMR through Logit regression model. The general form of the logistic equation of these socioeconomic variables with their expected signs was presented in separate model for each dependent variable.

\section{VARIABLE DESCRIPTIONS \\ Dependent variables}

Infant Mortality Rate (IMR):- The dependent variable is "the risk of death occurring in an age interval of 1-12 month period". It was noted as 1 if the child died before reaching 12 months of age and as 0 if otherwise. The estimated response probabilities in this case were strictly between zero and one.

Child Mortality Rate (CMR): - The dependent variable is "the risk of death occurring in an age interval in the 12-59 month period".

Explanatory (covariates) variables

The following covariates: level of mother education (Meduc) $(0=$ illiterate, $1=$ primary, $2=$ secondary $\&$ higher $)$; Levels of Mother's employment $($ Memp) $(0=$ unemployed, $1=$ employed $)$; Marital status of parents $(\mathrm{Ms})(0$ if union, 1 if not in union); Level of father's Education (Feduc) $(0=$ illiterate, $1=$ primary, $2=$ secondary $\&$ higher $)$; household income (Hhil) is continue; Household size (Hhsize) (0 if 1-5 family members, 1 if 6-10, 2 if more than 10); Type of household residence (Thhrsd) ( 0 for rural, 1 for urban); Access to safe water (aswtr) ( 0 if no access, 1 if better access); Access to health facilities (Hhahf) (0 if no access, 1 if better access); Religion (Rl) (1= Protestant, 2 = Orthodox, $3=$ Catholic, 4 = Muslim, 5 = others); Occupational status of household heads (Hhoccp) ( $1=$ if working in government office, 2 if working on trading of sales and services, 3 if working on farming and 4 if working on domestic services and other.

\section{RESULTS}

I. SUMMARY RESULTS OF DESCRIPTIVE ANALYSIS

Table 5: The summary results of IMR in the woreda for the year 2010-2017

\begin{tabular}{|l|l|l|l|l|l|l|}
\hline Years & Total live births & Total deaths & Total survives & Survival rates (\%) & Death rates (\%) & IMR \\
\hline 2010 & 2827 & 168 & 2659 & 94.06 & 5.94 & $\mathbf{5 9}$ \\
\hline 2011 & 2768 & 158 & 2610 & 94.29 & 5.71 & 57 \\
\hline 2012 & 2696 & 151 & 2545 & 94.40 & 5.6 & 56 \\
\hline 2013 & 2623 & 142 & 2481 & 94.59 & 5.41 & 54 \\
\hline 2014 & 2546 & 133 & 2413 & 94.78 & 5.22 & 52 \\
\hline 2015 & 2467 & 128 & 2339 & 94.81 & 5.19 & 52 \\
\hline 2016 & 2363 & 118 & 2245 & 95.01 & 4.99 & 50 \\
\hline 2017 & 202 & 10 & 192 & 95 & 4.95 & $\mathbf{5 0}$ \\
\hline
\end{tabular}

Source: Service Delivery Report of Humbo Woreda Health office for the year 2010-2017 
Table 6: The summary of results of IMR on urban-rural basis for the year 2017

\begin{tabular}{|l|l|l|l|l|}
\hline Variable & Description & Urban basis & Rural basis & District's basis \\
\cline { 2 - 5 } & & Frequency & Frequency & Frequency \\
\hline \multirow{3}{*}{ Infant mortality } & infant survived & 36 & 156 & 192 \\
\cline { 2 - 5 } & infant died & 1 & 9 & 10 \\
\cline { 2 - 5 } & Total & 37 & 165 & 202 \\
\cline { 2 - 5 } & IMR & $\mathbf{2 7}$ & $\mathbf{5 4}$ & $\mathbf{5 0}$ \\
\hline
\end{tabular}

Table 7: Summary of results of IMR in comparison with GTPE and National achieveme

\begin{tabular}{|c|c|c|c|c|c|}
\hline Variable & $\begin{array}{l}\text { Plan to be } \\
\text { achieved in } \\
2035\end{array}$ & $\begin{array}{l}\text { National } \\
\text { achievement } \\
\text { level in } 2015\end{array}$ & $\begin{array}{l}\text { Woreda's } \\
\text { achievement } \\
\text { level in } 2017\end{array}$ & $\begin{array}{lr}\begin{array}{l}\text { Differentials } \\
\text { compared }\end{array} & \text { as } \\
\text { National } & \text { to } \\
\text { achievement } & \text { level }\end{array}$ & $\begin{array}{ll}\text { Gaps } & \text { as } \\
\text { compared } & \text { to } \\
\text { GTPE } & \end{array}$ \\
\hline $\begin{array}{ll}\text { IMR } & \text { per } \\
1000 & \text { live } \\
\text { births } & \end{array}$ & 16 & 48 & 50 & Lower achievement & $\begin{array}{l}\text { Lower } \\
\text { achievement }\end{array}$ \\
\hline
\end{tabular}

IMR was 59 in 2011 and 50 in 2017. It has shown about $15 \%$ reduction over the past 8 years. To see this rate on urban-rural basis, it is 27 in urban and 54 in rural areas. IMR is higher in rural areas than urban areas of the district. It is comparable with both the national figure and the country's strategic plan. IMR 50 is higher than both the national level in 2015 and the country's strategic plan by the year 2035.

Table 8: The summary results of socio-economic characteristics on basis of IMR

\begin{tabular}{|c|c|c|c|c|c|}
\hline \multirow{2}{*}{$\begin{array}{l}\text { Hh } \\
\text { Cxs. }\end{array}$} & \multirow{2}{*}{$\begin{array}{l}\text { Categories of socio-economic Cxs. \& } \\
\text { their codes }\end{array}$} & \multicolumn{2}{|c|}{ birth \& death } & \multirow[b]{2}{*}{ IMR } & \multirow{2}{*}{$\begin{array}{l}\text { Correlation with } \\
\text { IMR }\end{array}$} \\
\hline & & $\begin{array}{l}\text { Total live } \\
\text { births }\end{array}$ & $\begin{array}{ll}\text { Noo } & \text { of } \\
\text { deaths } & \end{array}$ & & \\
\hline \multirow[t]{3}{*}{ Meduc } & $0=$ illiterate & 103 & 8 & 78 & \multirow[t]{3}{*}{ Inverse } \\
\hline & $1=$ primary educated & 74 & 1 & 14 & \\
\hline & $2=$ secondary and higher & 25 & 1 & 40 & \\
\hline \multirow[t]{2}{*}{ Memp } & $0=$ unemployed & 157 & 4 & 25 & \multirow[t]{2}{*}{ Direct } \\
\hline & $1=$ employed & 45 & 6 & 133 & \\
\hline \multirow[t]{2}{*}{ Ms } & $0=$ living in union & 178 & 3 & 17 & \multirow[t]{2}{*}{ Direct } \\
\hline & $1=$ not living in union & 24 & 7 & 292 & \\
\hline \multirow[t]{3}{*}{ Feduc } & $0=$ illiterate & 69 & 7 & 101 & \multirow[t]{3}{*}{ Inverse } \\
\hline & $1=$ primary educated & 83 & 2 & 24 & \\
\hline & $2=$ secondary and higher & 50 & 1 & 20 & \\
\hline \multirow[t]{3}{*}{ Hhsize } & $0=1-5$ family members & 170 & 2 & 12 & \multirow[t]{3}{*}{ Direct } \\
\hline & $1=6-10$ family members & 20 & 3 & 18 & \\
\hline & $2=>10$ family members & 12 & 5 & 417 & \\
\hline \multirow[t]{2}{*}{ aswtr } & $0=$ Not piped (Others) & 39 & 9 & 231 & \multirow[t]{2}{*}{ Inverse } \\
\hline & $1=$ Piped water & 163 & 1 & 6 & \\
\hline \multirow[t]{2}{*}{ Hhahf } & $0=$ not accessible & 62 & 8 & 129 & \multirow[t]{2}{*}{ Inverse } \\
\hline & $1=$ Accessible & 140 & 2 & 14 & \\
\hline \multirow[t]{2}{*}{ Thhrsd } & $0=$ Rural dweller & 165 & 9 & 54 & \multirow[t]{2}{*}{ Inverse } \\
\hline & $1=$ urban dweller & 37 & 1 & 27 & \\
\hline \multirow[t]{5}{*}{$\mathrm{R} 1$} & $1=$ Protestant & 164 & 2 & 12 & \multirow[t]{5}{*}{ Direct } \\
\hline & $2=$ Orthodox & 24 & 3 & 125 & \\
\hline & $3=$ Catholic & 11 & 4 & 364 & \\
\hline & $4=$ Muslim & - & - & - & \\
\hline & $5=$ Others & 3 & 1 & 333 & \\
\hline \multirow[t]{4}{*}{ Hhoccp } & 1=working gov't office & 75 & 2 & 27 & \multirow[t]{4}{*}{ Direct } \\
\hline & $2=$ working in sales & 50 & 3 & 60 & \\
\hline & $3=$ working on farming & 72 & 5 & 69 & \\
\hline & $4=$ working other services & 5 & 0 & - & \\
\hline
\end{tabular}

Source: Computation from survey data, 2018

To see the effect of socioeconomic characteristics on IMR, IMR was 78, 14 and 40 for children whose mothers have no education and primary, secondary and higher respectively. It was 25 when mothers are unemployed and 
133 when employed. It was $17 \& 282$ for children whose parents are living in union and not in union respectively. It was 101, $24 \& 20$ children whose fathers have no education and primary, secondary and higher respectively. All the deaths were in households in which their income was low. IMR was $12,18 \& 417$ for children whose households have 1-5, 6-10 and > 10 family members respectively. It was $54 \& 27$ for children whose households live in rural and in urban respectively. It was $231 \& 6$ for children whose households have no access to safe water and have better access respectively. IMR was $129 \& 14$ for children whose households have no access to health facilities and have better access. It was $27,60, \& 69$ for children whose households heads were working in government offices, working on sales \& services and working on farming respectively. It was $12,125,364 \& 333$ for children whose parents were Protestant Christianity followers, Orthodox, Catholic and other religion followers respectively.

Table 9: The summary results of CMR in the woredafrom the year 2010-2017

\begin{tabular}{|lllllll|}
\hline Years & Total live births & Total deaths & Total survives & Survival rates \% & Death rates \% & CMR \\
\hline 2010 & 21,234 & 1,359 & 19,875 & 93.60 & 6.4 & $\mathbf{6 4}$ \\
\hline 2011 & 19,811 & 1,208 & 18,603 & 93.90 & 6.1 & 61 \\
\hline 2012 & 18,576 & 1,096 & 17,480 & 94.10 & 5.9 & 59 \\
\hline 2013 & 17,563 & 1,001 & 16,562 & 94.3 & 5.7 & 57 \\
\hline 2014 & 16,701 & 935 & 15,766 & 94.41 & 5.59 & 56 \\
\hline 2015 & 16,180 & 857 & 15,323 & 94.7 & 5.3 & 53 \\
\hline 2016 & 15,722 & 802 & 14,920 & 94.9 & 5.1 & 51 \\
\hline 2017 & 252 & 12 & 240 & 95.24 & 4.76 & $\mathbf{4 8}$ \\
\hline
\end{tabular}

Table 10: The summary of results of CMR on urban-rural basis for the year 2017

\begin{tabular}{|l|l|l|l|l|}
\hline \multirow{2}{*}{ Variable } & Description & Urban basis & Rural basis & District's basis \\
\cline { 3 - 5 } & & Frequency & Frequency & Frequency \\
\hline \multirow{3}{*}{ Child mortality } & child survived & 37 & 203 & 240 \\
\cline { 2 - 5 } & child died & 1 & 10 & 12 \\
\cline { 2 - 5 } & Total & 38 & 213 & 252 \\
\cline { 2 - 4 } & CMR & $\mathbf{2 6}$ & $\mathbf{4 7}$ & $\mathbf{4 8}$ \\
\hline
\end{tabular}

Source: own computation from survey data, 2018

Table 11: Summary of results of CMR in comparison with GTPE and National achieveme

\begin{tabular}{|l|l|l|l|l|l|}
\hline Variable & $\begin{array}{l}\text { Plan to be } \\
\text { achieved in } \\
2035\end{array}$ & $\begin{array}{l}\text { National } \\
\text { achievement } \\
\text { level in 2015 }\end{array}$ & $\begin{array}{l}\text { Woreda's } \\
\text { achievement } \\
\text { level in 2017 }\end{array}$ & $\begin{array}{l}\text { Compared to } \\
\text { National level } \\
\text { in 2015 }\end{array}$ & $\begin{array}{l}\text { Gaps compared } \\
\text { to GTPE }\end{array}$ \\
\hline CMR & $<\mathbf{3 0}$ & $\mathbf{5 8}$ & $\mathbf{4 8}$ & $\begin{array}{l}\text { Better } \\
\text { achievement }\end{array}$ & $\begin{array}{l}\text { Lower } \\
\text { achievement }\end{array}$ \\
\hline
\end{tabular}

Source: own computation from survey data, 2018\& FMoH, 2014

Based on the above table 9, 10 \& 11 above, CMR in the district was 64 in 2010 and 48 in 2017 . It has shown about $25 \%$ reduction between the two periods. To see the rate on urban-rural basis, it is 26 in urban and 47 in rural areas. It is higher in rural than urban areas. CMR in 2017 is comparable with both the national figure and its strategic plan to be achieved by the year 2035. Hence, CMR 48 is lower than the national child mortality rate in 2015 and higher than its strategic plan to be achieved by the year 2035 . 
Table 12: The summary results of socio-economic characteristics on basis of CMR

\begin{tabular}{|c|c|c|c|c|c|}
\hline \multirow[t]{2}{*}{ HhCxs. } & \multirow{2}{*}{$\begin{array}{l}\text { Categories of socio-economic } \\
\text { Cxs. }\end{array}$} & \multicolumn{3}{|l|}{ birth \& death } & \multirow{2}{*}{$\begin{array}{l}\text { Correlation with } \\
\text { CMR }\end{array}$} \\
\hline & & $\begin{array}{l}\text { No of live } \\
\text { births }\end{array}$ & $\begin{array}{l}\text { No } \\
\text { deaths }\end{array}$ & CMR & \\
\hline Meduc & $\begin{array}{l}0=\text { None educated } \\
1=\text { primary educated } \\
2=\text { secondary and higher }\end{array}$ & $\begin{array}{l}128 \\
94 \\
30\end{array}$ & $\begin{array}{l}9 \\
3 \\
-\end{array}$ & $\begin{array}{l}70 \\
32 \\
0\end{array}$ & Inverse \\
\hline Memp & $\begin{array}{l}0=\text { unemployed } \\
1=\text { employed }\end{array}$ & $\begin{array}{l}187 \\
65\end{array}$ & $\begin{array}{l}11 \\
1\end{array}$ & $\begin{array}{l}59 \\
16\end{array}$ & Inverse \\
\hline Ms & $\begin{array}{l}0=\text { living in union } \\
1=\text { not in union }\end{array}$ & $\begin{array}{l}198 \\
54\end{array}$ & $\begin{array}{l}5 \\
7\end{array}$ & $\begin{array}{l}25 \\
130\end{array}$ & Direct \\
\hline Feduc & $\begin{array}{l}0=\text { No educated } \\
1=\text { primary educated } \\
2=\text { secondary and higher }\end{array}$ & $\begin{array}{l}89 \\
98 \\
65\end{array}$ & $\begin{array}{l}10 \\
2 \\
-\end{array}$ & $\begin{array}{l}112 \\
20 \\
0\end{array}$ & Inverse \\
\hline Hhsize & $\begin{array}{l}0=1-5 \text { family members } \\
1=6-10 \text { family members } \\
2=>10 \text { family members }\end{array}$ & $\begin{array}{l}190 \\
35 \\
27\end{array}$ & $\begin{array}{l}3 \\
5 \\
4\end{array}$ & $\begin{array}{l}16 \\
143 \\
148 \\
\end{array}$ & Direct \\
\hline aswtr & $\begin{array}{l}0=\text { Not piped (Others) } \\
1=\text { Piped water }\end{array}$ & $\begin{array}{l}59 \\
193\end{array}$ & $\begin{array}{l}10 \\
2\end{array}$ & $\begin{array}{l}170 \\
10\end{array}$ & Inverse \\
\hline Hhahf & $\begin{array}{l}0=\text { not accessible } \\
1=\text { Accessible }\end{array}$ & $\begin{array}{l}82 \\
170\end{array}$ & $\begin{array}{l}7 \\
5\end{array}$ & $\begin{array}{l}85 \\
29\end{array}$ & Inverse \\
\hline Thhrsd & $\begin{array}{l}0=\text { Rural dweller } \\
1=\text { Urban dweller }\end{array}$ & $\begin{array}{l}204 \\
48\end{array}$ & $\begin{array}{l}10 \\
2\end{array}$ & $\begin{array}{l}49 \\
42\end{array}$ & Inverse \\
\hline $\mathrm{Rl}$ & $\begin{array}{l}1=\text { Protestant } \\
2=\text { Orthodox } \\
3=\text { Catholic } \\
5=\text { Others }\end{array}$ & $\begin{array}{l}194 \\
29 \\
26 \\
3\end{array}$ & $\begin{array}{l}3 \\
4 \\
5 \\
0\end{array}$ & $\begin{array}{l}16 \\
138 \\
192 \\
0\end{array}$ & Direct \\
\hline Hhoccp & $\begin{array}{l}1=\text { working in gov't office } \\
2=\text { working in sales } \\
3=\text { working on farming } \\
4=\text { working on domestic services } \\
\& \text { others }\end{array}$ & $\begin{array}{l}72 \\
90 \\
89 \\
1\end{array}$ & $\begin{array}{l}2 \\
4 \\
6\end{array}$ & $\begin{array}{l}28 \\
45 \\
67 \\
0\end{array}$ & Direct \\
\hline
\end{tabular}

Source: own computation from survey data, 2018

To see the effect of socioeconomic characteristics on CMR, CMR was 70,32, \& 0 for children whose mothers have no education and primary, secondary and higher respectively. CMR was $59 \& 16$ for children whose mothers were unemployed and employed respectively. It was $25 \& 130$ for children whose parents are living in union and not in union respectively. It was $112,20 \& 0$ for children whose fathers have no education and primary, secondary and higher respectively. No deaths were occurred in households of higher monthly income level. It was $16,143 \&$ 148 for children whose households have 1-5, 6-10 and > 10 family members respectively. CMR was 49 \& 42 for children whose households live in rural and in urban respectively. It was 170 \& 10 for children whose households have no access to safe water and have better access respectively. It was $85 \& 29$ for children whose households have no access to health facilities and have better access. It was $28,45 \& 67$ for children whose households heads were working in government offices, working on sales $\&$ services and working on farming respectively. It was 16, $138 \& 192$ for children whose parents were Protestant, Orthodox, and Catholic followers respectively.

\section{SUMMARY RESULTS OF ECONOMETRIC ANALYSIS}

We start with fitting regression model. Table 14 below summarizes the result obtained from binary logit regression analysis. From this table, we can identify candidate covariates to be considered for the multivariable model. Mother education, mother employment status, area of residence, access to safe water and access to health facilities are significant at the 5\% level of significance in the first model whereas working status of mother, marital status of parents, level of father's education, family size, access to safe water, access to health facilities, and occupational status of household heads are significant from the second model.

\section{ECONOMETRIC DIAGNOSIS TESTS}

It is important to check whether the basic assumptions of the models are met or not, then to estimate the specified models. According to the diagnosis test results; no multicollinearity problem in both models (VIF $=4.32 \& 3.73$ ); no hetroscedasticity problem (prob-chi $\left.{ }^{2}=0.0834 \& 0.7238\right) \&$ the models were fitted with the data (the goodness of fit test result p-value $0.9629 \& 0.7195)$. 
Vol.10, No.13, 2019

Table 14: The summarized regression results of the first model using Odds ratio

\begin{tabular}{|c|c|c|c|c|c|c|}
\hline \multicolumn{2}{|c|}{ Logistic regression } & \multicolumn{5}{|c|}{ Number of obs $=202$} \\
\hline & & \multicolumn{5}{|c|}{ LR $\operatorname{chi} 2(11)=60.03$} \\
\hline & & \multicolumn{5}{|c|}{ Prob $>\operatorname{chi} 2=0.0000$} \\
\hline \multicolumn{4}{|c|}{ Log likelihood $=-9.7896218$} & \multicolumn{3}{|c|}{ Pseudo R2 $=0.7541$} \\
\hline IMR & Odds Ratio & Std. Err. & Z & $\mathrm{P}>\mathrm{Z}$ & \multicolumn{2}{|c|}{ [95\% Conf. interval] } \\
\hline Meduc** & -0.024 & .0410 & 2.18 & 0.029 & .009 & .684 \\
\hline Memp $^{* *}$ & 8.438 & 2.244 & 2.23 & 0.026 & 2.258 & 13.154 \\
\hline Ms & 1.415 & 2.634 & 0.19 & 0.852 & .0368 & 4.384 \\
\hline Feduc & -0.126 & .203 & 1.29 & 0.198 & .054 & 2.945 \\
\hline Hhil & -0.992 & .031 & 0.24 & 0.809 & .833 & 1.055 \\
\hline Hhsize & 1.103 & 1.339 & 0.08 & 0.936 & .102 & 3.924 \\
\hline Thhrsd** & -0.117 & .071 & 2.06 & 0.039 & 0.0445 & .645 \\
\hline aswtr** & -0.404 & .0112 & 2.00 & 0.046 & .018 & .905 \\
\hline Hhahf** & -0.340 & .105 & 2.08 & 0.038 & .214 & .731 \\
\hline Hhoccp & 2.083 & 2.580 & 0.59 & 0.554 & .184 & 3.607 \\
\hline Rl & 7.269 & 4.103 & 1.43 & 0.154 & .477 & 10.807 \\
\hline cons & 52.330 & 5.38 & 0.64 & 0.521 & .0299 & 91.718 \\
\hline
\end{tabular}

\begin{tabular}{|l|l|l|l|l|l|l|}
\hline CMR & Odds Ratio & $\begin{array}{l}\text { Std. } \\
\text { Err. }\end{array}$ & Z & P>z & \multicolumn{2}{|l|}{$[95 \%$ Conf. Interval } \\
\hline Meduc & -0.302 & .380 & 0.95 & 0.341 & .026 & 3.552 \\
\hline Memp** & -0.61 & .208 & 2.17 & 0.030 & .078 & .984 \\
\hline Ms** & 2.306 & 5.898 & 2.13 & 0.033 & .153 & 3.467 \\
\hline Feduc*** & -0.151 & .372 & 2.64 & 0.008 & .012 & 1.887 \\
\hline Hhil & -0.982 & .027 & 0.66 & 0.510 & .929 & 1.037 \\
\hline Hhsize** & 7.471 & 13.251 & 2.43 & 0.015 & 2.31 & 11.163 \\
\hline Thhrsd & -0.155 & .290 & 0.99 & 0.320 & .004 & 6.121 \\
\hline Aswtr*** & -0.3384 & .674 & 2.86 & 0.004 & .0682 & .6791 \\
\hline Hhahf** & -0.375 & .584 & 2.11 & 0.035 & .1777 & .791 \\
\hline Rl & 3.327 & 2.934 & 1.36 & 0.173 & .591 & 8.731 \\
\hline Hhoccp** & 2.829 & 2.940 & 2.15 & 0.031 & 1.309 & 3.314 \\
\hline cons & .1361 & .5007 & -0.54 & 0.588 & .01004 & 1.845 \\
\hline
\end{tabular}

\section{DISCUSIONS}

The effect of socioeconomic characteristics of households on IMR

Infants of whose mothers are educated at primary and higher level are 0.024 times in better position of survival probability as compared to those of whose mothers are illiterate. This suggests as mother's education improves the survival probability of infants. Infants of whose mothers are employed are 8.438 times more likely died as compared to those whose mothers are unemployed by suggesting working status of mother affects the survival probability of infants. Infants who reside in urban areas of the district are 0.117 times less likely died as compared to those who reside in rural areas by suggesting residing in urban areas improves the survival probability of infants. Infants who have better access to safe water were 0.404 times in better position of survival probability as compared to those who have no access to safe water by suggesting having better access to safe water improves the survival probability of infants. Infants who have better access to health facilities are 0.34 times in better position of survival probability as compared to those who have no access to health facilities by suggesting having better access to health facilities improves the survival probability of infants.

\section{The effect of socioeconomic characteristics of households on CMR}

Children of age 12-59 months of whose mothers are unemployed were 0.61 times more likely died as compared to those whose mothers are employed by suggesting the working status of mother improves the survival probability of children of age 12-59 months. Children of whose parents are not living in union are 2.306 times more likely died as compared to those of whose parents are living in union by suggesting not living of parents in union affects the survival probability of children of age 12-59 months. Children of whose fathers are educated at primary and higher level are 0.151 times less likely died as compared to those of whose fathers are illiterate and suggests as father's education improves the survival probability of children of age 12-59 months. Children who live in large family size are 7.471 times more likely died as compared to those who live in small family size by suggesting as having large family members affects the survival probability of children of age 12-59 months. Children whose 
family has better access to safe water are 0.3384 times less likely died as compared to those who have no access to safe water by suggesting having better access to safe water improves the survival probability of children of age 12-59 months. Children whose family has better access to health facilities are 0.375 times less likely died as compared to those who have no access to health facilities by suggesting having better access to health facilities improves the survival probability of children of age 12-59 months. Children of whose household heads are working on farming are 2.825 times more likely died as compared to those whose household heads are working in trading of sales \&services and government offices by suggesting working in government office improves the survival probability of children of age 12-59 months.

\section{SUMMARY OF MAJOR FINDINGS}

IMR of the woreda is 50 whereas CMR is 48 . About $15 \%$ reduction of IMR and $25 \%$ reduction of CMR have been registered over the past 8 years in the district. IMR is higher as compared to both GTPE reduction plan by the year 2035 and the national achievement level in 2016 whereas CMR is higher as compared to GTPE and lower than the current national achievement level. Level of mother's education, working status of mother, place of household residence, access to safe water, and access to health facilities are standing as major determinants of IMR whereas working status of mother, marital status of parents, level of father's education, family size, access to safe water, access to health facilities, and occupational status of household heads are standing as major determinants of CMR.

\section{CONCLUSIONS}

The study concluded that socio-economic factors such as level of mother's education, residing in urban areas, having better access to safe water, and having better access to health facilities improve the survival probability of infants. This is because of mother education equips mothers with the necessary knowledge of how to care for their kids; urban areas have better access to basic services than rural areas; using safe water to reduce the incidence of disease and infection of infants; having better access to health facilities to improve the situation to get health services. Level of father's education, having better access to safe water, and having better access to health facilities improve the survival probability of children of age 12-59 months as literate father engages in highly paid job and earn high income to improve child nutrition and hence its survival probability. Not living of parents in union, having large family size and occupational status of household heads other than government office and trading of sales and services affect the survival probability of children of age 12-59 months. This is due to the reason that mothers in unstable marriages would not get support from their partners during child care which can increase the risk of childhood mortality; large family size has high dependency ratio; government workers and traders earn secured family income throughout the year than other occupations. Working status of mother affects the survival probability of infants as infants are highly dependent of their mothers and working mothers spent more time on their work \& less time to care for their kids but; improves the survival probability of children of age 12-59 months as children in this age are less dependent of mothers than infants and working mothers earn additional income to improve their household income level, hence improves child nutrition.

\section{RECOMMENDATIONS}

The study advises the government (local, zonal and federal) to play key roles in improving the socio-economic status of the rural poor as urban households are in better position of socio-economic conditions than rural households in the district; insure the benefit of rural people from the expansion of infrastructures (health facilities, safe water, road, and marketing facilities); improve the quality of existing health services ( organize health posts and health centers with full of necessary equipment, medicines, ethically \& technically competent health workers); create appropriate staying room for infants at work place with full of necessary facilities, allow working mothers with adequate resting time after delivery; address the key socio-economic characteristics of households that have been identified as determining factors of IMR and CMR by the existing Health, education and economic policies. encourage NGOs to participate in activities that improve the socio-economic conditions in the district; give awareness creation training on the key issues of the finding; advantages of education; how to improve home environment to practice modern life; advantages of having small family size \& birth spacing; how to develop tolerance with among marriage partners at the time of conflict.

\section{REFERENCES}

Amare Deribew (2016). Trends, causes and risk factors of mortality among children under five in Ethiopia, Based on 1990-2013 EDHS data.

Bereka SG, Habtewold FG, Nebi TD. (2016). Under five Mortality of children and its Determinants in Ethiopian Somali Regional State, Eastern Ethiopia. Research Article Vol.11 No.3:507;

CSA (2016).Ethiopia Demographic and Health Survey. Addis Ababa, Ethiopia. Pp.1-33

Desta Mekonnen (2011). Children under-five mortality in Ethiopia: The role of socioeconomic, demographic and biological factors in the previous five years 
FMoH (2014). Policy and Practice Information for Action, quarterly health bulletin, vol.6.

Iram, U. and Butt, M. S. (2008). 'Socioeconomic Determinants of Children under-five mortality in Pakistan: Evidence from Sequential Probit Model', International Journal of Social Economics.

Kumar, P. and Gemechis (2010). Children under-five mortality in Ethiopia: As statistical analysis Appr.

Mosley, W.H. and Chen, L.C. (1984). An analytical framework for the study of child survival in developing countries. Population and Development Review 10:25-45. Bulletin of the World Health Organization 2003, $81(2)$

Mustafa, E. and Odimegwu, C. (2008). Socioeconomic determinants of infant mortality in Kenya: Analysis of Kenya DHS 2003.

Mutunga, C. J. (2007). 'Environmental Determinants of Child Mortality in Kenya', World Institute for Development Economics Research, UN University, Research Paper No. 2007/83.

Tariku Dejene and Eshetu Girma (2013). Social determinants of under- five mortality in Ethiopia, Based on 2011 EDHS. Research ArticleVol.5, No.5, 879-884 (2013).

Transitional Government of Ethiopia (1993b). Health Policy of the Transitional Government of Ethiopia. Addis Ababa, Ethiopia: Transitional Government of Ethiopia.

UNICEF. (2008). The state of the world's children 2009: maternal and newborn health (Vol. 9). Unicef.

World Bank (2010). The changing wealth of nations: Measuring sustainable development in the new millennium, Washington, DC.

World Health Organization Report (2015). Global health observatory data.

Yemane T. (1967). Statistics, an Introductory Analysis, 2nd Ed., New York.Harper and Row. 